Journal of Language Teaching and Learning, Linguistics and Literature

ISSN 2338-4778 (Print)

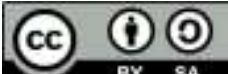

ISSN 2548-4192 (Online)

Volume 8, Number 1, June 2020

pp. $116-125$

\title{
Talking Sticks as a Technique to Stimulate the Students' Speaking Performance in EFL Classroom
}

\author{
St. Hartina \\ sthartina@iainpalopo.ac.id \\ Institut Agama Islam Negeri Palopo, Indonesia
}

Received: 26 April 2020 Accepted: 16 May 2020

DOI: $10.24256 /$ ideas.v8i1.1317

\begin{abstract}
Talking sticks is an alternative teaching technique to support students in developing their speaking performance. Holding the talking sticks empower the deep communication between people and allow opportunities to speak up during the classroom. Thus, the present study is to stimulate the students' speaking performance in EFL classroom by utilizing the talking sticks. It applied classroom action research which was conducted in four stages; planning, action, observation, and reflection. A total of 22 students is the subject of speaking tests, observation, and interviews. The results demonstrated a significant improvement of students' speaking performance which can be seen in the mean score result and the number of students passing the minimal standard score. The mean score gained 9.43 higher than in the pre-test and $77 \%$ of students passed the minimal standard score. Both of these criteria indicated that utilizing the talking stick can boost the students' speaking performance
\end{abstract}

Keywords: talking sticks; students' speaking performance, EFL classroom 
St. Hartina

Talking Sticks as a Technique to Stimulate the Students' Speaking Performance in EFL classroom

\section{Introduction}

The development of speaking skills in EFL classroom has grown rapidly in the last four decades (Derakhsan, 2015). It is used in the real-life language-use context to communicate effectively (Seong, 2017) the best way in which the speaker can express himself through language (Linda, 2019). It is learned better in the group and should be taught everywhere. Teachers need to define what academic experiences are that students can undergo as they come into their social life after their study (Akbar, 2017). So, teachers have a significant role in making interaction and enhancing students' speaking skills (Anuradha et al: 2014). To get communicative goals, varying based activities and tasks can be applied in the classroom (Kumari,2014) and create a class condition which is stimulating the student to study (Byrne, 2002). Especially in speaking class, the teachers are responsible for creating the class activities, work with students to find their interest as the vital factors for speech improvement (The commission on English Curriculum, 2009).

The problem is found in speaking classes when students cannot contribute any ideas to the group and fail to understand things that are worth saying (Singh, 2007). Some students are less eager to talk because they are shy and lack confidence. Fear of making mistakes, stupid or incomprehensible (Brown, 2007 P.265) affects their speaking performance. Almost all EFL students worry when they have to talk in class (Liu, 2006) without preparation. The teachers usually do not provide equal opportunities for all students to speak. Only students talk about themselves while students like silence because they do not have the responsibility to participate in the class. It means that the teachers failed to apply an appropriate method which enhanced all students to speak actively. Based on this phenomenon, a speaking teaching method is needed that allows all students to speak.

The Talking Sticks developed by Spencer Kagan is a teaching techniques that can be used in cooperative learning where students must dare to express their opinions with the help of a stick (Suprijono: 2015). Initially, this Talking Sticks is a piece of wood used by Indian tribes in America to let everyone speak their mind during council meetings, a type of tribal meeting (Knockwood,1992). It's usually used to decide who has the right to speak. Garret (2002) described that Talking Sticks can be in the form of ordinary sticks of any kind or any size. Whoever holds the stick then he has the power of the word to talk and the others must be quiet and listen. Candler (2013) claimed that it can use plastic chips or craft sticks to equalize participation in class. This strategy can facilitate students to speak and help students to acquire the course material structurally (Wardhana, 2016)

The application of Talking Sticks according to Candler (2013) begins by appointing one student as the leader of the discussion. The leader will distribute three sticks to each student and open a discussion. Students who want to respond the discussion must put one of their sticks into a plastic cup. The number of sticks in hand indicates the number of opportunities to talk. If students have run out of 


\section{St. Hartina}

Talking Sticks as a Technique to Stimulate the Students' Speaking Performance in EFL classroom

sticks then they must be quiet and listen to other students until all the sticks are collected into the glass. On the other hand, Suprijono (2015) modified the application of Talking Sticks to be more interesting. The stick is passed one by one clockwise. The only students who are allowed to say something during the discussion are only a person who holds the stick. Students who receive the stick are required to respond to questions from the teacher so on. When the stick scrolls from other students, it should be accompanied by music. The final is the teacher gives the reflection on the material they have learned by reviewing of all students' answer.

This technique is more creative than using the traditional way by appointing students one by one. It provides equal opportunities for each student to participate in discussions because the opportunity to speak matches the number of sticks they have. Thus, this study tried to use the Talking Sticks in stimulating the students' speaking performance in the EFL classroom.

\section{Method}

This research was conducted by applying classroom action research. Through purposive sampling, there were twenty-two students of the English education department studying in the 2nd semester were selected as the subject of the research. The data were obtained from the oral test in pre-test and post-test, observation and interview. It was conducted in two-cycles which were divided into 4 steps: planning, acting, observing, and reflecting for each cycle as followed:

Figure 1: Model of Cyclical in action research (Kemmis and McTaggart,1998)

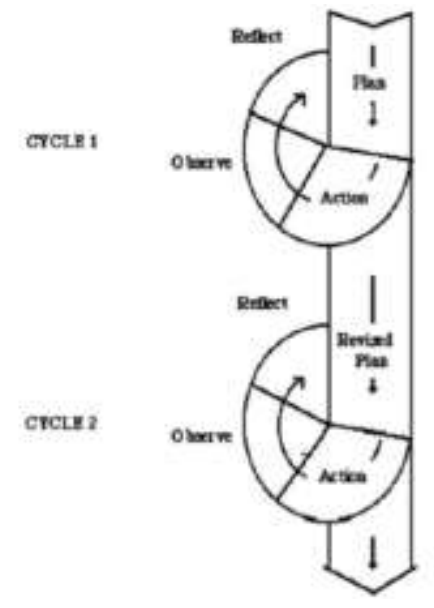

\section{Planning}

Before starting the lesson, the teacher prepared the research instrument, instructional media and material for the treatment. In this case, the research instruments consisted of the topic and rubric score for oral testing, observation checklist for observing and question lists for interviewing. The media and material were the wooden sticks and the discussion topic based on the lesson plan. Before giving the treatment, the students were given the oral pre-test in the form of 


\section{St. Hartina}

Talking Sticks as a Technique to Stimulate the Students' Speaking Performance in EFL classroom

asking the students' opinion about the certain topic. To measure the students' speaking ability, it used the rubric of speaking score adapted from Heaton (1988:100) which is consisted of accuracy, fluency and comprehensibility.

\section{Acting}

The lesson was started by delivering the objective of learning and explained the application of the Talking Sticks. The teacher gave a text about the topic and explained what the issue talking about. The students were allowed to conduct a mini discussion in pairs to share their taught about the subject matter. After brainstorming, the students sat in a big circle. The leader started the discussion by distributing three sticks to each student. After opening the discussion, students were allowed to give interruptions or answer questions. Anyone who responded to questions or gave interruptions must place their stick in the middle of the table. If a student had run out of sticks, the student was quiet and listened to the others. The activity continued until all the sticks had been placed.

\section{Observing}

The teacher observed all the events and activities by using the observation checklist and field note to note all the activities during the learning process. In checklist observation, there were several aspects as the indicator whether or not the students' speaking improved during the treatment process. At the last meeting, the researcher interviewed the students in order to find out their response toward the Talking Sticks technique that they had already followed. After treatment, the teacher gave an oral post-test by asking the students' opinion about the certain topic. Students' speaking abilities are measured using the following scale:

Table 1: Speaking Assessment Scale

\begin{tabular}{|c|c|}
\hline Scale & Classification \\
\hline $91-100$ & Excellent \\
\hline $81-90$ & Very Good \\
\hline $71-80$ & Good \\
\hline $61-70$ & Fair \\
\hline $51-60$ & Poor \\
\hline Less than 50 & Very Poor \\
\hline
\end{tabular}

\section{Reflecting}

The reflecting was analyzing the data taken from the oral test, observation checklist and interview as the feedback of the teaching-learning process. The researcher analyzed the data to find out the strength and weakness of the treatment and decided the next action to improve the treatment process. The 


\section{St. Hartina}

Talking Sticks as a Technique to Stimulate the Students' Speaking Performance in EFL classroom

indicator appeared in observation checklist, the mean score of the pre-test and post-test, and interview result became a reflective material to find out the effect of talking stick on students' speaking ability.

To measure the achievement of learning targets and the successful implementation of this method, there are two criteria and indicators applied as followed:

1. The mean score in the post-test is higher more 5 points than in the pre-test.

2. There are $75 \%$ of students reach 71 score as the minimum standard score.

\section{Result}

The data finding in the speaking test was the accumulation of accuracy, fluency, and comprehensibility as presented in the following chart:

Chart 1: The Accuracy, Fluency and Comprehensibility Score

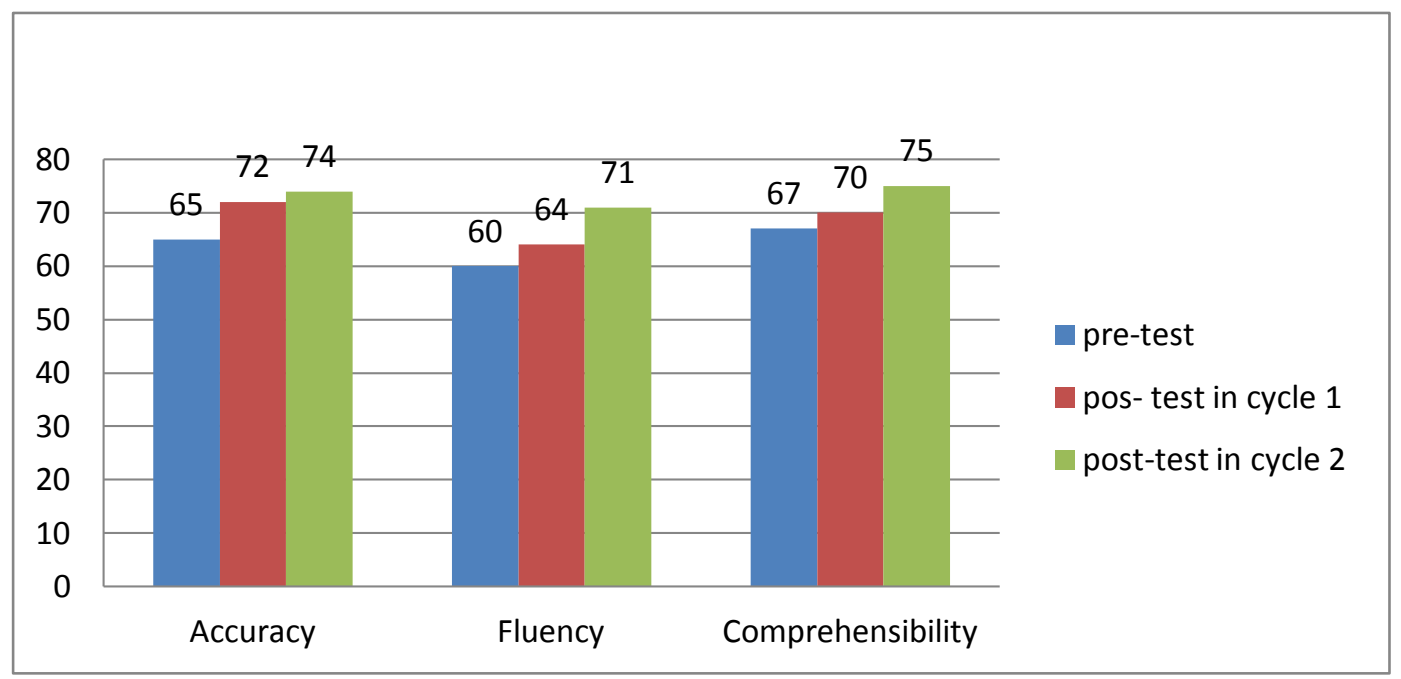

The accumulation of accuracy, fluency, and comprehensibility as the speaking assessment aspect calculated into the mean-score of the speaking test. It gained continuously which is illustrated in the following chart:

Chart 2: The mean score of the speaking test

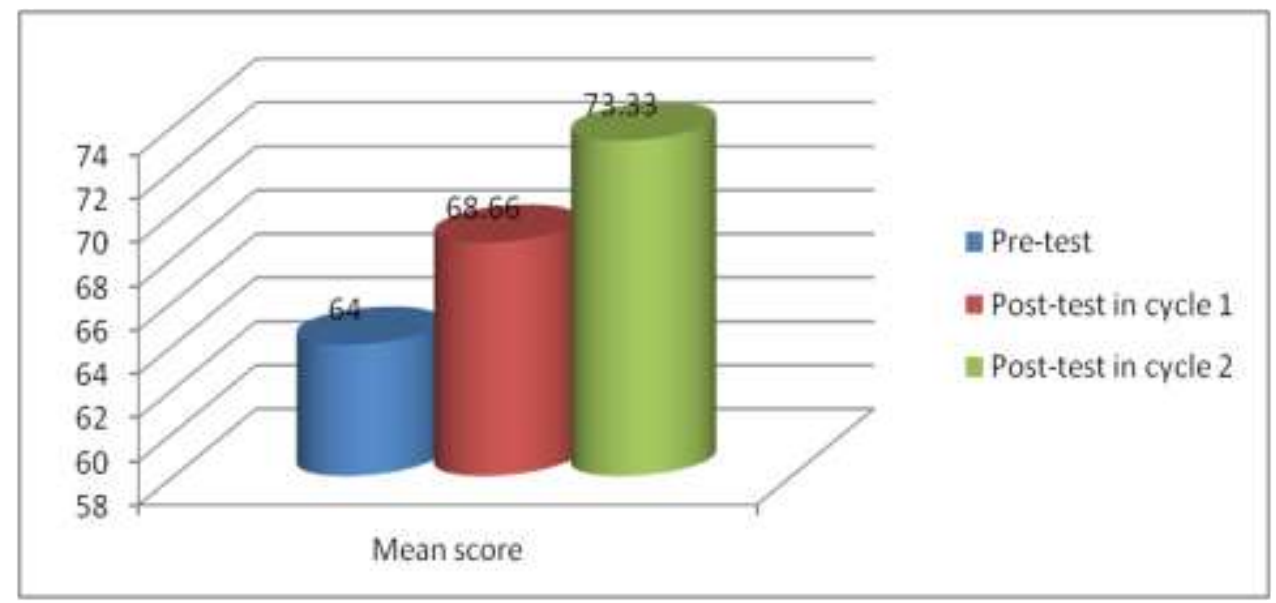


Talking Sticks as a Technique to Stimulate the Students' Speaking Performance in EFL classroom

Also, another indicator that measures the achievement target is the number of students who reach 71 as the minimum standard score. The number has been added each cycle as demonstrated in the following table:

Table 2: The percentage of the students' passing the minimum standard score

\section{Description of cycle 1}

The data analysis performed the mean score of students' speaking performance in cycle 1 was 68.66 higher 4.66 than in the pre-test. The mean score results that did not reach 5 points was established that the first criterion of success failed to accomplish. The other data established that only $54 \%$ got the score up to 71 as the minimum standard score. Both of the two data analyzes indicated that the students' speaking performance did not achieve the criteria of success.

Observation data showed that some students were enthusiastic followed the learning process, but some were still confused. They had difficulty compiling sentences to be delivered. Some looked nervous when forced to spend the sticks they have. Based on the results of the interview, students who were less active in the class due to lack of vocabulary and did not have enough ideas on the topics discussed. Besides, the teacher did not provide enough information about the topic discussed and the topic chosen was not familiar to students. The weaknesses in cycle 1 were evaluated to find out the better treatment for applying in cycle 2 .

\begin{tabular}{|c|c|c|}
\hline Test & $\begin{array}{c}\text { The number of } \\
\text { students }\end{array}$ & Percentage \\
\hline Pre-test & 7 & $31 \%$ \\
\hline $\begin{array}{c}\text { Post-test in cycle } \\
1\end{array}$ & 12 & $54 \%$ \\
\hline $\begin{array}{c}\text { Post-test in cycle } \\
2\end{array}$ & 17 & $77 \%$ \\
\hline
\end{tabular}

\section{Description of Cycle 2}

The implementation of Talking Sticks was modified to fix the weaknesses in cycle 1 . The teacher chose the leader by turning the sticks clockwise while singing a song. At the end of the song, whoever hold the stick would lead the discussion. To attract the student's attention, the teacher drilled the vocabularies related to the topic and used the PowerPoint as the visual aid. The topic chosen was also more interesting and familiar with students. Improvements made at this stage provide positive changes. It was indicated by the increasing number of mean-scores of the post-test which was 9.43 higher than the pre-test. The number of students who were able to get a score of 71 also increased from $54 \%$ to $77 \%$ from the previous cycle. Both of these achievements have reached indicators of successful of this technique. 


\section{St. Hartina}

Talking Sticks as a Technique to Stimulate the Students' Speaking Performance in EFL classroom

Observation result showed that students were more confident to talk. The use of a Talking Sticks that started with a song made the classroom atmosphere more relaxed. The time needed to spend all the sticks became shorter. Even some students were still enthusiastic to talk but had run out of sticks. From the results of the interviews, the students argued that they were encouraged to talk because they wanted to immediately spend the stick in hand. It forced them to listen to every piece of information in the discussion to provide interruptions and answers. Based on the results, it could be inferred that there is a significant improvement over the previous cycle.

\section{Discussion}

The results of data analysis showed a significant increase in students' speaking abilities until the second cycle. This increase is evidenced by two achievement indicators; (1) the mean-score in the pre-test increased by 9.33 in the post-test. If the mean-score increases by more than 5 , the stimulus was given is considered successful. (2) The number of students who reach a score of 71 as much as $77 \%$ is considered to have exceeded the achievement target of $75 \%$. Also, observation showed that students were more enthusiastic about conveying ideas using this technique than appointing them one by one. Based on the interview results, it was explained that the sticks had an effect which forced students to argue. To spend sticks in hand students must actively participate in class. This is in line with Derakhsan (2015) that Learners should take part in oral activities to exchange spontaneously their thought in second language speaking (Derakhshan et al., 2015). The Talking Sticks provide equal opportunities for each student to speak so that there are no students who dominate learning activities. Let the learners speak actively with whatever English knowledge they have (Anuradha et al, 2014) to raise their skills step by step

One of the Principles for improving speaking skills is that speaking should incorporate activities in group work (Oradee, 2012). Talking Sticks that are played in groups will encourage each member in the group to participate. The opportunity for the stick holder to speak will activate discussion activities in the form of groups to practice the ability of each student to speak. In line with the opinion of Murcia (2001) that students who participate in discussion activities encourage other students to take part to negotiate. Students will be surprised at their abilities and intelligence. Talking Sticks that are played in groups will form a continuous communication pattern in the form of conversation. One way to practice speaking skills is Learners should participate in the conversation (Brown, 2007). By using this techniques, teachers as course designers give students' communications experiences that differ them from everyday communication in general (Akbar, 2017)

The principle of success in mastering a second language according to Brown (2007, p.160) that the ability to take risks is regarded as an essence for "successful 


\section{St. Hartina}

Talking Sticks as a Technique to Stimulate the Students' Speaking Performance in EFL classroom

learning of a second language". During the Talking Sticks activity, students must be ready to talk with all their abilities when it is their turn to speak. With the courage to take turns speaking, it will stimulate students to unleash the potential they have. This will improve their ability to master a second language, especially speaking.

Kagan (2000) argues that this technique has the strengths to attract the students' preparation to be more serious in learning. It trains students to comprehend and master the material because students are given time to learn and recall the materials vividly. Who gets the sticks must answer the question or speak up. So, it is not only stimulating the students' speaking performance, the students to speak up, but it also builds fun activities in the classroom. The strength by using this technique is: (1) it keeps the students' attention, (2) helps the teacher to ensure that students listen and understands the material given or not, (3) helps the teacher know what is unknown and what is already known by students, (4) students are more active in speaking than teachers.

It is one of the innovative techniques to make the students speak up and express their ideas confidently. Learning by using Talking Sticks encourages students to express their ideas. The teachers should be more creative in designing the classroom to stimulate and motivate them to convey their ideas orally.

\section{Conclusion}

From the results of data analysis, it was concluded that Talking Sticks can improve students' speaking abilities. Talking Sticks is very appropriate to be used in improving students' abilities because each student has an equal opportunity to speak, increase confidence to speak, and raise the ability to listen and think critically to issue opinions. The principle of applying the Talking Sticks is in line with the principles of developing speaking skills so that it is very effectively used in learning English in the EFL classroom.

In suggestion for the next researcher, it is recommended to use a different Talking Sticks procedure by adapting the current model.

\section{References}

Akbar. (2015). Anatomy of oral academic presentation skills: A course design for college students of English department. IDEAS: Journal on English Language Teaching and Learning, Linguistics and Literature, 5(2). https://doi.org/10.24256/ideas.v5i2.25.

Anuradha, RV, Raman, G, \&Hemamalini, HC. (2014). Methods of Teaching English. Hyderabad:

Brown, H. D. (2007). Principle of language learning and teaching. White Plains, NY: Pearson Longman. 
St. Hartina

Talking Sticks as a Technique to Stimulate the Students' Speaking Performance in EFL classroom

Byrne, D. (2002). English Teaching Perspective. London: Longman Groups Ltd. Delucia-Waack, Janice L., et al. 2004. Handbook of Group Counseling and Psychotherapy. London: University Press.

Candler. L Talking Sticks Discussions: 2013 Teaching Resources, (Milken Education, 2013), p. 1 .

Celle-Murcia, M. (2001).Teaching English as a second language or foreign language (2nd ed.). New York: Newbury House.

Commission on the English curriculum. (2009).Newyork: Applicatiion.century. Crofts, INC.

Derakhshan, A., \& Shirmohammadi, M. (2015). The difficulties of teaching the English language: The relationship between research and teaching. International Journal of Linguistics, 7(1), 102-110. http://dx.doi.org/10.5296/ijl.v7i1.6648

Garret, J. T. (2002).The Cherokee Full Chircle: A Practical Guide to Ceremonies and Traditions. New York: Bear and Company Inc.

Heaton, J.B. (1988). Writing English Language Text. New York: Longman Inc.

Kagan, S. (2000). Cooperative Learning. California: Kagan Publishing.

Kemmis, S \& Taggart, R.(1988). The Action Research reader. Melbourne, Victoria: Deakin University Press

Knockwood. (1992). One Space Learning Circle and Active Learning in English Communication Class.Retrieved on October 13 $13^{\text {rd, }} 2012$ from http://www.terrydean.org/7

Kumari, AV. (2014). Methods of Teaching English. Guntur: New Era Publications.

Linda, S (2019). Designing English Speaking Materials using Task Based Language Teaching (TBLT) for Islamic Economics students. IDEAS: Journal on English Language Teaching and Learning, Linguistics and Literature, 7(2). https://doi.org/10.24256/ideas.v7i2.25.

Liu, M. H. (2006). Anxiety in Chinese EFL students at different proficiency levels. System, 34(1), 301-316.Neelkamal Publications.

Nunan, D. (2003). Practical English Language Teaching Teacher's Text Book. McGraw-Hill

Oradee, Th. (2012). Developing speaking skills using three communicative activities (discussion, problem-solving, and role- play). International Journal of Social Science and Humanity, 2(6), 532- 533.

Seong. Y. (2017). Assessing L2 Academic Speaking Ability: The Need for a Scenariobased Assessment Approach, Columbia University Working Papers in Applied Linguistics \& TESOL, Vol. 17 (2), p. 36

Singh, M.S. (2007). The Teaching of English, New Delhi: Adhayayan Distributors (pp.65-66)

Suprijono, A.(2015). Cooperative Learning: Teori \& Aplikasi PAIKEM (Pembelajaran Aktif Inovatif Kreatif Efektif Menyenangkan). Yogyakarta: Pustaka Pelajar, p. 128 
St. Hartina

Talking Sticks as a Technique to Stimulate the Students' Speaking Performance in EFL classroom

Wardana, W.S. (2016). Paper Airplane and Talking Stick Learning Methods to Increase Students' Understanding about Management Information System Courses, IOSR Journal of Business and Management (IOSR-JBM), Vol. 18 (9), p. 164 